\title{
HOAX IN SOCIAL MEDIA AND IT'S THREATS TO ISLAMIC MODERATION IN INDONESIA
}

\author{
Erwin Jusuf Thaib \\ Sultan Amai State Islamic Institute, Gorontalo \\ erwinjthaib@iaingorontalo.ac.id
}

\begin{abstract}
Hoax is a human problem in this era of information. The presence of hoaxes causes information consumers to find it difficult to distinguish between true or false information, especially those that spread on social media. The main problem in this research is how hoaxes can threaten religious moderation in Indonesia. This study aims to analyze how hoax information on social media threatens the moderation of Islam in Indonesia. This research uses the library research method. The data were obtained from relevant library data sources and analyzed using a qualitative approach. The findings show that many hoaxes are conveyed along with religious and political information. Hoax on the political aspect aims to bring down political opponents or the government. In the religious aspect, hoaxes are used to attack opposing religious beliefs or schools. Hoaxes on these two aspects, especially religion, have the potential to divide people and destroy religious moderation in society. This research is expected to contribute to the study of communication, especially media and information.
\end{abstract}

Keywords: Hoax, Indonesia, Islamic moderation, social media.

Abstrak: Hoax merupakan permasalahan umat manusia di era banjir informasi ini. Kehadiran hoax menyebabkan konsumen informasi sulit membedakan mana informasi yang benar atau palsu terutama yang menyebar di media sosial. Permasalahan utama dalam penelitian ini adalah bagaimana hoax bisa mengancam moderasi beragama di Indonesia.Penelitian ini bertujuan untuk menganalisis bagaimana informasi hoax di media social mengancam moderasi Islam di Indonesia. Penelitian ini menggunakan metode kepustakaan. Data diperoleh dari sumber data pustaka yang relevan dan dianalisis dengan pendekatan kualitatif. Temuan Penelitian ini menunjukkan bahwa hoax banyak disampaikan bersamaan dengan informasi agama dan politik. Hoax pada aspek politik bertujuan untuk menjatuhkan lawan politik atau pemerintah berkuasa. Pada aspek agama, hoax digunakan untuk menyerang paham atau aliran keagamaan yang berseberangan. Hoax pada kedua aspek ini utamanya agama berpotensi memecah belah umat dan menghancurkan moderasi beragama dalam masyarakat. Penelitian ini diharapkan berkontribusi terhadap kajian komunikasi utamanya media dan informasi.

Kata kunci: Hoax, Indonesia, media social, moderasi Islam.

\section{A. Introduction}

One of the needs of modern humans today is information. They need any information about their life. Even the level of dependence on information is a distinctive marker for modern human existence. This is what drives the growth of mass media in this modern era, be it print media or even electronic media. Even in the internet era, mass media variants have also 
developed with the presence of online media. The presence of the internet has influenced the evolutionary process of modern human communication and interaction. ${ }^{1}$

Various information can be found in the mass media to answer the human need for information. The large number of mass media present today provides consumers with choices for a variety of information. Political, economic, cultural, sports, religious and various other information are mass media content that is often found and fills the information space that humans need in this information age.

The presence of social media in modern human life has played a role in supplying fast information for today's information needs. Social media with its flexible character, easily accessible to anyone, anytime and anywhere, has played its influence as a source of information for the millennial generation and has played a role in shaping the character of their lives. Social media enables the implementation of interaction, communication and collaboration among users effectively, quickly, precisely and relatively cheaply. ${ }^{2}$

All kinds of information scattered on social media further strengthen the character of modern humans who are very dependent on the existence of information. Whenever and wherever they continue to get the supply of information they need. However, it is unfortunate that social media cannot be completely relied upon as a source of information because invalid information was found but spreads so fast. This invalid information is not unintentional. On the contrary, this is something that is deliberately formed and disguised in various ways as if it were truth in order to achieve the purpose of its maker. This invalid information is popularly known as hoax.

Social media has indeed become a place for hoax information about various things to grow. The character of social media where anyone can construct information about anything without any control regarding its validity then spread on social media so that hoax information appears more often on social media. Hoaxes are news or information that contains things that are not certain or that are really not facts. ${ }^{3}$ In hoax information, facts are twisted, the truth is hidden. ${ }^{4}$ Hoax as false information that is deliberately formed is actually made for certain benefits such as political gain. So, in moments related to politics, hoaxes can easily be found on social media that aim to attack or bring down political opponents.

Outside the political context, hoax information on social media can be linked to religious issues. This is mainly due to the diversity of religious understanding in society, so that claims often arise to favor certain religious understandings and of course drop other religious understandings. Hoax information related to religious issues actually attracts the attention of social media users because it is usually peppered with religious arguments so that it is highly trusted by social media users. This phenomenon is actually very dangerous in the context of building moderate diversity. Hoax information on social media actually divides the community into their respective religious groups and brings down one another. How dangerous hoax information circulating on social media is against the moderation of Islam, especially in the context of Indonesian society, will be the main discussion in this article.

\footnotetext{
${ }^{1}$ Mulawarman dan Aldila Dyas Nurfitri, "Perilaku Pengguna Media Sosial beserta Implikasinya Ditinjau dari Perspektif Psikologi Sosial Terapan," Buletin Psikologi 25, no. 1 (2017): 36.

${ }^{2}$ Setiawan Assegaf, "Evaluasi Pemanfaatan Media Sosial Sebagai Sarana Knowledge Sharing," Jurnal Manajemen Teknologi 16, no. 3 (2017): 273.

${ }^{3}$ Chriatiany Juditha, "Interaksi Komunikasi Hoax di Media Sosial Serta Antisipasinya," Jurnal Pekommas 3 (2018): 31.

${ }^{4}$ Gumgum Gumilar, et.al., "Literasi Media: Cerdas Menggunakan Media Sosial dalam Menaggulangi Berita Palsu (Hoax) Oleh Siswa SMA," Jurnal Pengabdian pada Masyarakat 1, no. 1 (2017): 36.
} 


\section{B. Theoretical Review}

\section{The Evolution of Hoaxes Information: Theoretical and Practical}

In general, hoaxes are understood as fake news. Mc Dougall (1958) defines a hoax "deliberately concocted untruth made to masquerade truth". ${ }^{5}$ The word hoax when traced from the history of the origin of the word was first popularly used in the mid to late 18th century. Hoaxes have a tendency to deceive the public. Hoax has the characteristics of deceiving a wide, popular and massive audience. ${ }^{6}$ The word hoax has actually been around for hundreds of years. Around $1808^{7}$ first appeared the term hoax in English. Written in a book by Linda Walsh entitled Sins Against Science. Hoax also comes from the words of the ancient magicians "Hocus Pocus", Latin for "Hoc est corpus", witches used it as a weapon to trick others with their own words which turned out to be deceptive. The description of hoax, which means a hoax, is also found in a book called Candle in The Dark by Thomas Ady in 1965. Around 2006 the use of the term hoax became popular, obtained from a film called Hoax, starring Richard Gere and directed by Lasse Halstorm. ${ }^{8}$

The presence of hoaxes in the public sphere, especially in the mass media, is actually not a new thing, even though this phenomenon has only emerged in the era of the current flood of information. At first hoax news was used by some people as a joke, now it has caused unrest. Hoax news or fake news has spread widely and has had a negative impact. Therefore, with the hope that we will not easily accept all the news that is circulating, especially about news which contains things that are not good, do not make sense and the source of the news is unclear. It should be underlined, hoax news spreads easily in a short time, because most of the individuals themselves also spread the news without knowing the truth. ${ }^{9}$ The rapid dissemination of information without heeding the ethics of news in online media makes it difficult for readers to distinguish which information is true and which is falsified on Facebook, WhatsApp, Line, and massive instant message information for spreading fake news or hoaxes. ${ }^{10}$ On social media, various types of hoaxes can be found, including: fake news, click bait (trap link), confirmation bias, misinformation, satire, post-truth and propaganda. ${ }^{11}$

Hoaxes have undergone an evolution from what was originally just a joke, but then turned into dangerous information. Hoax is a force that can be used to form public opinion. And because the purpose is evil, the damaging effects of hoaxes are especially dangerous. In this modern era, hoax information is even deliberately made for the purpose of attacking certain parties. This was done, among other things, to take political advantage of the hoax information. In fact, sometimes this hoax information becomes a business field that generates a lot of money because of the many political moments that have resulted in the birth of many competitions for political power. Hoaxes are used to bring down political opponents by spreading negative issues so that voters will turn away from them.

\footnotetext{
5Pratiwi Utami, "Hoax in Modern Politics: The Meaning of Hoax in Indonesian Politics and Democracy," Jurnal Ilmu Sosial dan Ilmu Politik 22, no. 2 (2018): 88.

${ }^{6}$ Gun Gun Heriyanto, "Hoax dan Krisis Nalar Publik: Potret Perang Informasi di Media Sosial," in Aep Wahyudin dan Manik Sunuantari, Melawan Hoax di Media Sosial dan Media Massa (Yogyakarta: Turstmedia Publishing, 2017), 4.

${ }^{7}$ Roida Pakpahan, "Analisis Fenomena Hoax di Berbagai Media Sosial dan Cara Menanggulangi Hoax," Prosiding Konferensi Nasional Ilmu Sosial dan Teknologi (KNiST), 2017, 480.

${ }^{8}$ Gallant Karunia Assiddik, "Kajian Identifikasi dan Upaya Penangkalan Pemberitaan Palsu (Hoax) pada Pembelajaran Bahasa Indonesia," dalam Kongres Bahasa Indonesia 2018, 9. (http://repositori.kemdikbud.go.id/) ${ }^{9}$ Gallant Karunia Assiddik, Kajian Identifikasi dan Upaya Penangkalan Pemberitaan Palsu (Hoax) pada Pembelajaran Bahasa Indonesia, 9.

${ }^{10}$ Abdul Majid, "Fenomena Penyebaran Hoax dan Literasi Bermedia Sosial Lembaga Mahasiswa Universitas Muslim Indonesia," Jurnal Komodifikasi 8 (2019): 228.

${ }^{11}$ Dedi Rianto Rahadi, "Perilaku Pengguna dan Informasi Hoax di Media Sosial," Jurnal Manajemen dan Kewirausahaan 5, no. 1 (2017): 62.
} 
The use of hoaxes for certain interests is greatly assisted by the attitude of the community who is not critical in managing the information it receives. Hoaxes will tend to be accepted as truth without any action to clarify whether the information received has the truth or not. In many cases, hoax information has resulted in fatal chaos. Without clarifying, the parties who feel aggrieved take action which results in material damage and loss of human life. The phenomenon of this destructive hoax information is very dangerous if it continues to grow in society.

\section{Social Media and Hoax Information}

There are many questions about what social media really means. In fact, there is no single or fixed definition or definition of social media. The notion of social media generally describes the social media process itself which emphasizes the process of interaction between individuals by creating, sharing, exchanging, and modifying ideas or ideas in the form of virtual or network communication. However, there are some definitions from the following experts:

Firstly, Kotler and Keller: Social media is the media used by consumers to share text, images, sound, and informational videos with others. ${ }^{12}$

Secondly, social media (Facebook, Twitter, Youtube and Flickr) is a historical necessity that has brought changes in the process of human communication. The communication process, which has been carried out only through face-to-face communication, group communication, mass communication, has changed completely with the development of communication technology today, especially the internet. These changes will bring consequences to the communication process. The communication process that occurs has consequences at the individual, organizational and institutional levels. ${ }^{13}$

Thirdly, Taprial and Kanwar: Social media is the media used by someone to be social, or get online social by sharing content, news, photos and others with other people.14

Fourth, Kaplan and Haenlein: Social media is a group of internet-based applications that build on the ideological foundations of Web 2.0, and that allow the creation and exchange of User Generated Content. From this definition, Kaplan and Haenlein state that social media is a group of internetbased applications built on the ideological foundations of Web 2.0 which is a platform for the evolution of social media that allows the creation and exchange of User Generated Content. ${ }^{15}$

From the three definitions of social media above, it can be concluded that social media is a vehicle for socializing oneself in the form of sharing text, video images. In this way people socialize themselves in a virtual community connected with the help of the internet.

\section{a. Characteristics of Social Media}

According to Taprial and Kanwar, social media has several characteristics as follows:

Firstly, accessibility. Social media can be accessed easily by anyone who has a device connected to the internet. Therefore, social media is very easy to use by anyone and does not require special skills for it. Anyone with online access can use social media to communicate with others around the world.

Secondly, interactivity. Communication through social media takes place in two ways or even more. Hence, social media users can interact with other social media users. Everyone can ask questions, discuss a product or other things that match their interests.

Thirdly, longevity / volatility. Sent messages can be stored and accessed again for long periods of time. Even these messages can be edited and updated again at any time as needed.

\footnotetext{
${ }^{12}$ Philip Kottler and Kevin Lane Keller, Handbook of Research of Effective Advertising Strategies in the Social Media Age (Cambridge: IGI Global, 2016), 338.

${ }^{13}$ Nurudin, "Media Sosial Baru dan Munculnya Revolusi Proses Komunikasi," Jurnal Komunikator 5 (2010): 83.

${ }^{14}$ Varinder Taprial and Priya Kanwar, Understanding Social Media (London: Ventus Publishing ApS 2012), 8.

${ }^{15}$ Andreas M. Kaplan dan Michael Haenlein, Social Media: Back to the Roots and Back to the Future (Paris: ESCP Europe, 2010), 101.
} 
Fourth, affordability (Reach). Internet offers unrestricted access to all content contained in the invisible world. Everyone can access the internet from anywhere and anytime.

Fifth, speed. Messages that have been created on social media can be accessed by everyone in the same network or group or forum or community as soon as the message is published. We can communicate with audiences without going through many obstacles that affect the delivery of a message. The response or responses given by the audience are also instant or immediate so that we can dialogue with the audience in real time. ${ }^{16}$

It can be said that the characteristics possessed by social media are the main strengths or advantages of social media. This allows everyone to connect with other people and access information available on the internet. Interactions that are carried out online make no more barriers between social media users. Social media is generally used to keep in touch with friends or family, meet people who have the same interests, discuss issues, share opinions, give and answer questions, read reviews and so on.

Humans use social media as a means of learning communication to increase knowledge and make the best decisions. Social media is also used in the world of business, politics, entertainment and others to target potential consumers and target consumers, interact with consumers, build or shape a company image and manage the company's reputation online.

\section{b. Social Media Functions}

To understand the function of social media, Kietzmann et. al. stated that the function of social media can be explained by using the Honeycomb framework which describes social media using seven pillars, namely identity, conversation, sharing, presence, relationship, reputation, and group. The descriptions of the seven pillars are as follows:

Firstly, identity: how the user presents himself.

Secondly, conversations: how users communicate with other users.

Thirdly, sharing: how users exchange content, distribute content, and receive content.

Fourth, presence: how users know the presence of other users.

Fifth, relationship: how users relate to each other.

Sixth, reputation: how users know the content and social position of other users.

Seventh, groups: how users are in a community or group. ${ }^{17}$

The seven functions above really represent social media as a vehicle for self-socialization even though they don't actually meet physically. In this day and age, self-interaction is only measured and represented by social media, which makes each other virtually connected. Social media deconstructs traditional social relationship patterns that require physical encounters. In the era of social media, humans are connected to each other by means of social media.

Personally, social media provides space for each individual to connect with many other human characters who socialize through social media. As for companies, social media is an effective showroom for the products and services they produce. In general, there are many benefits that can be gained from the existence of social media in modern human life today.

The spread of hoax information in society is influenced by the massive use of social media in society. Social media is a unique marker for the millennial generation. This generation feels that their life is not perfect if they do not have connections to social media. Social media itself is an information platform that is open and freely accessible to anyone. That's why a variety of information can be found on social media including hoax information.

The era of the internet, which was followed by the presence of the latest communication technology media and social media in society, gave birth to a community context that was flooded with information. 18 The presence of the internet has an influence on communication activities. The internet has taken part in human life both positively and negatively. After connecting to the

\footnotetext{
16 Taprial and Kanwar, Understanding Social Media, 28-29.

17Ibid., 31-32.

${ }^{18}$ Maria D. Molina, dkk., "'Fake News' is Not Simply False Information: A Concept Explication and Taxonomy of Online Content," in American Behavioral Scientist (California: SAGE Publications, 2019), 1.
} 
internet everyone can enjoy the positive impact of the internet. Among them is the availability of a lot of information both text, voice and images that can be accessed anytime and anywhere. The existence of the internet also makes it easier for humans to interact with other people without feeling obstructed by distance. According to Graham, interaction or interactivity is a way that runs between users or machines (technology) by enabling users and devices to connect interactively. Interaction is one of the characteristics of cyber media as a communication tool.19

Through cyber media, every human being can be interactively connected to each other at the same time. Even the use of cyber media can represent the involvement of communication patterns, which at first could only communicate directly or face to face. It is in this context that information is easily obtained from various sources. In the past, information only came from limited sources and was considered authoritative as news sources, then in this era of information flood, information came from anywhere and from anyone without any clarity as to whether the source of information had the authority to disseminate information. In this situation, people absorb information from social media without the ability to filter the accuracy of the information. They then become entangled in information sharing activities and sometimes the information shared is a hoax.

\section{Methods}

This research was conducted with a library research approach. The main research data is in the form of relevant library sources. Data in the form of library analysis, statistical data, related information sources, are obtained from books, journals, and releases from parties related to social media information. The data obtained were analyzed using qualitative analysis. The data analysis process was carried out by classifying and organizing the data found for later data analysis and determining research conclusions.

\section{Results and Discussion}

\section{The Reality of Hoax Information on Social Media}

Social media is a phenomenon of the times. Currently, almost all levels of society are connected to social media. Sarwoto Atmosutarno in the Social Media Optimization Guide book for the Ministry of Trade of the Republic of Indonesia, said that until 2014 the number of internet users in Indonesia reached 70 million or $28 \%$ of the total population. Social media users like Facebook make up around 50 million or $20 \%$ of the total population, while Twitter users make up 40 million or $16 \%$ of the total population. The figures above will continue to grow from year to year, because they are supported by a large base of mobile / cellular phone and internet users. For this reason, it can be concluded that almost or even more than a third of the total population of Indonesian people are now internet literate..$^{20}$

This figure has increased based on data in January 2020. In terms of cellphone use, there are 338.2 million active cellphones in Indonesia, or the equivalent of 124 percent of the population. There are 174.5 million active internet users, equivalent to 64 percent of the population. There are 160 million social media users in Indonesia. This figure is equivalent to 59 percent of the population. The average time for internet usage per day is 7 hours 59 minutes, and the average time for using social media is 3 hours 26 minutes. ${ }^{21}$

\footnotetext{
${ }^{19}$ Fita Fathurokhmah, "Menghadapi Krisis Hoax di Media Sosial: Jurnalisme Online dalam Regulasi Media di Indonesia," in Aep Wahyudin dan Manik Sunuantari, Melawan Hoax di Media Sosial dan Media Massa (Yogyakarta: Turstmedia Publishing, 2017), 235.

${ }^{20}$ Eko Sumadi, "Dakwah dan Media Sosial: Menebar Kebaikan tanpa Diskriminasi," Jurnal Al-Tabsyir 4, no. 1 (Juni 2016): 174-175.

21Source: https://wearesocial.com/
} 
On a global scale, according to the latest data in January 2018, the number of internet users is 4.021 billion people, or the equivalent of 53 percent of the 7,593 billion total world population. There are 3.196 billion active social media users and 5.135 billion cellphone users or 68 percent of the population. ${ }^{22}$ In January 2020, this figure underwent a significant change. When the world's population reached 7.75 billion people, the number of people using the internet grew to 4.54 billion or the equivalent of 59 percent of the population. Worldwide, there are 3.80 billion social media users or the equivalent of 49 percent of the population. Cell phone users reach 5.19 billion, equivalent to 67 percent of the world's population..$^{23}$

The data above shows that the majority of the population, both on a world scale and in Indonesia, are the majority of active internet users and connected to social media. They are the ones who always absorb information from social media. Various information is spread through social media. It can be ascertained that all types of information have a consumer base who is always looking for the information they like via the internet or social media. One of the many information circulating on social media is hoax information. A survey conducted by Ismail Fahmi (Drone Emprit) shows that 92, 40 percent of hoaxes in Indonesia are spread through social media. $^{24}$

Hoax is indeed an information phenomenon that can easily be found on social media in Indonesia. This hoax message was spread in chains on social media without knowing where this information came from. And without ever having tested the validity of this information. In general, hoax information on social media can be related to two aspects, namely politics and religion.

\section{a. Hoax on Political Aspect}

The political agenda becomes fertile ground for the development of hoax information on social media. Hoax is seen as a powerful weapon to destroy the reputation of political opponents. Information containing hoaxes attacked certain political participants without clear sources. And the party attacked by hoaxes is busy making clarifications about the hoax issue that is blowing. Even though it has been clarified, usually not everyone can access the clarification and tends to believe the hoax issue that exists. And this is very detrimental to those affected by hoax issues

In Indonesia, there are at least two political moments where the hoax issue dominates the social media space of society. The two events were the 2017 DKI Jakarta Regional Head Election ${ }^{25}$ and the 2019 Presidential Election of the Republic of Indonesia. At the moment of the 2017 DKI Jakarta Regional Election, there were more than 1900 reports of alleged hoaxes that occurred ahead of the regional elections and there were more than a thousand reports confirmed that they were hoaxes, mostly about politics, related to the Jakarta Pilkada, and religious issues played a major role. ${ }^{26}$

In the 2017 DKI Jakarta Regional Election, the hoax issue does not only play in the political realm but also religious and ethnic issues. Jargon about the governor of Muslim-governor NonMuslim, Chinese and Indigenous, about the personality of the candidate, as well as many other hoax issues that are easily found milling about on social media.

In the 2019 election for the President of the Republic of Indonesia, the hoax issue also circulated in this political moment. As with the DKI Jakarta Regional Election in 2017, at the moment of the 2019 Presidential Election of the Republic of Indonesia, the hoax issue which is a combination of political and religious issues can be easily found on social media. A lot of hoax information is circulating on Facebook, chain messages on WhattsApp, and other social media

\footnotetext{
${ }^{22}$ See Kompas.com, October 18, 2018.

${ }^{23}$ Source: https://wearesocial.com/

${ }^{24}$ Adiprasetio, et. al., "Hoax, Reproduksi dan Persebaran: Suatu Penelusuran Literatur," Jurnal Pengabdian kepada Masyarakat 1, no. 4 (2017): 275.

${ }^{25}$ Henri Septanto, "Pengaruh HOAX dan Ujaran Kebencian sebuah Cyber Crime dengan Teknologi Sedrhana di Kehidupan Sosial Masyarakat,” Jurnal KALBI Scientia 5, no. 2 (2018): 158.

${ }^{26}$ Source: Khairul Ashar, Turn Back Hoax
} 
platforms. Issues circulating include the issue of the PKI, China, the religion of the presidential candidates. In addition, there are many hoaxes related to the election process, for example relating to the neutrality of the KPU, about the results of different quick counts or real counts, about winning claims from candidates, and attempts to question the validity of the election results. The electoral process is continuously peppered with hoax information, both before its implementation and after it is implemented.

The two political events above provide an overview of how hoax information is used for political purposes. Incidents like this have been repeated in various political moments in Indonesia. The two examples above have become phenomenal because they have caught the attention of all Indonesians and even the international community. Currently every government political decision will always be followed by misleading hoax information. For example, hoax information following the ratification of the Omnibus Law by the DPR. Lots of hoaxes circulating about this matter, and mainly attacking the DPR and the Government. This phenomenon is actually a continuation of the same phenomenon during political moments as previously described.

\section{b. Hoax on the Religious Aspect}

Apart from dealing with political issues, one of the themes that often fills hoax content on social media is religion. Even the issue of political hoaxes is often filled with religious issues. This shows that religious issues are seen as having a strong influence in influencing many people so they are often used as hoax content on social media.

Hoax information related to religion, especially in Indonesia, has actually had a lot of very damaging consequences, both for the structure of community life, as well as the order of life as a nation and state. The religious-nuanced conflict that occurred in Ambon City, Maluku in 1999, illustrates the devastating effects of hoax information. Even conflicts with religious nuances that subsequently occurred in various regions in Indonesia such as in Poso, Central Sulawesi were also caused by hoax issues circulating in society.

The circulation of hoax issues with religious nuances in Indonesian society today is also heavily influenced by the presence of new religious ideas in Indonesia which, if traced, have links to global religious understanding. In this condition, it seems as if there is intense competition between religious beliefs or schools. This competition also seems to position local Indonesian religious ideas such as NU and Muhammadiyah, with new religious understandings such as Wahabi and Salafi.

There are many local religious traditions that have existed for a long time in the religious practice of the Indonesian people, which are then misled or blamed. This is a picture of the existence of rivalry between religious understandings in Indonesia. These attacks on religious practices are usually indirect and formal, but through social media by presenting memes that attack certain parties. Sometimes even twisted the facts. For example, by quoting the opinion of NU figures to recite the birthday of the Prophet Muhammad.

In addition to the examples above, there are many other hoaxes related to religion that were created with the aim of inciting the emotions of other Muslims. Hoaxes like this are, for example, in the form of a caption about the massacre of Muslims in certain locations. Or also hoaxes about the halalness of certain food products or even certain places to eat. Hoaxes about the Day of Judgment, and many more hoaxes associated with religion.

Religion is indeed a hoax tool that always appears on social media. This is because the religious aspect is able to attract the attention of many people. Religion can also be a trigger for solidarity and fanaticism in the name of faith. Therefore, hoax information with religious ingredients in it always comes to the surface because it is seen as effective in achieving the hoax's goal itself. 


\section{Threat of Hoax Information against Religious Moderation}

Hoax information on social media has become a problem that is not only around the information itself but also concerns problems in almost all aspects of human life. This is because information is an inseparable part of modern human life, so that information is an aspect that also colors the life of modern society today.

One aspect of Indonesian society exposed to this hoax information problem is moderate religious life. Indonesia has long been known for its diversity of religions, ethnicities, languages, cultures, customs and other forms of diversity and this diversity is almost never a problem. Diversity such as cultural diversity, family background, religion and ethnicity interact with each other in the Indonesian community. ${ }^{27}$ In the religious field, in Indonesia there are at least five major religions, namely Islam, Protestant Christianity, Catholicism, Hinduism and Buddhism. This religious diversity has never been a problem. Relations between religions work well because of the moderate views held by all religious adherents.

Religious moderation is indeed the key word for the harmony of religious relations that is built in Indonesia. According to Lukman Hakim Saifuddin, religious moderation means referring to the attitude of reducing violence, or avoiding extremes in religious practice. Religious moderation must be understood as a balanced religious attitude between the practice of one's own religion (exclusive) and respect for the religious practices of others with different beliefs (inclusive). This balance or middle ground in religious practice will undoubtedly prevent us from excessive extremes, fanaticism, and revolutionary attitudes in religion. Religious moderation is a solution to the presence of two extremes in religion, the ultra-conservative pole or the extreme right on the one hand and the liberal or the extreme left on the other. ${ }^{28}$

Islam itself as a religion emphasizes its teachings on moderate religious aspects. Islam from its semantic aspect as a religion of safety and peace has shown the essence of moderate Islam. And this can be seen from the long history of Islam in Indonesia. Moderation is the core teaching of Islam. Moderate Islam is a religious understanding that is very relevant in the context of diversity in all aspects, including religion, customs, ethnicity and the nation itself. ${ }^{29}$ Islam itself as a religion emphasizes its teachings on moderate religious aspects. Islam from its semantic aspect as a religion of safety and peace has shown the essence of moderate Islam. And this can be seen from the long history of Islam in Indonesia. Moderation is the core teaching of Islam. Moderate Islam is a religious understanding that is very relevant in the context of diversity in all aspects, including religion, customs, ethnicity and the nation itself.

Hoax threats on social media against the moderation of Islam in Indonesia include:

First, the threat of radicalism. Radicalism is a real threat to the moderation of Islam in Indonesia. Radicalism is a notion that wants to make drastic changes by using violence. This radicalism will be even more dangerous if it is attached to ideological aspects such as religion. Meanwhile on social media, this hoax information has a lot to do with this ideological aspect. Religion is a very popular selling point in the production of this hoax. Hoaxes with religious content on social media usually contain hate speech, attacks on the intended parties, and sometimes followed by radical actions such as terrorism.

Second, the threat of divide of Muslims. Another danger contained in hoax information on social media is the divide of Muslims. Without realizing it, hoax information on social media has the tendency to pit Muslims against each other. This practice of fighting against one another is primarily aimed at religious practices carried out by religious schools that exist in Indonesia. Hoax information like this usually aims to foster mutual hatred among Muslims. This mutual hatred can

\footnotetext{
${ }^{27}$ Agus Akhmadi, “Moderasi Beragama dalam Keragaman Indonesia," Jurnal Diklat Keagamaan 13, no. 2 (2019): 45.

28Tim Penyusun Kementerian Agama RI, Moderasi Beragama, 18.

${ }^{29}$ Mohammad Fahri dan Ahmad Zaenuri, "Moderasi Beragama di Indonesia," Jurnal Intizar 25, no. 2 (2019): 95.
} 
lead to acts of blasphemy against each other and sometimes even leads to physical contact between supporters of religious sects. ${ }^{30}$

Third, the threat of intolerance. Diversity in religion, ethnicity and culture as well as other elements of diversity is a reality that cannot be avoided in Indonesia, a very pluralistic country from many aspects. Even so, efforts to manage this diversity so that it will always be the collective strength of the Indonesian nation is under threat from continuous hoax information on social media. There is a lot of misleading information on social media that tends to reject diversity and encourage intolerance, especially in matters of religion. Religion seems to be a wall that separates Indonesian society into separate ideological boxes, something that is contrary to the noble values of Islam itself.

The analysis above shows how hoax information on social media threatens the moderation of Islam in Indonesia. Islam is one of the values that shapes the character of the Indonesian nation as a polite, tolerant and peace-loving nation, but with the spread of hoax information spreading on social media lately it seems that Indonesian Muslims have lost their identity as a peace-loving people.

In the end, hoaxes can no longer only be seen as chain messages without meaning on social media. More than that, hoax information must be seen as a real threat to the life of the Indonesian people. The public must be made aware of hoax information on social media and its dangers for the harmony of people's lives. Massive literacy efforts are needed so that people can become healthy social media users. With this literacy, people are not trapped as producers, consumers, and carriers of hoax information on social media.

\section{E. Conclusion}

Hoaxes that were originally just jokes have evolved into perverted and dangerous information and have become massive especially in the era of social media. Social media, which was created to support the supply of information for its users, has become a vehicle for hoaxes to circulate.

Hoax information on social media is a real threat to the moderation of Islam in Indonesia. This information, which is generally related to politics and religion, threatens the moderation of Islam in Indonesia through three forms, namely radicalism, division and intolerance.

These three forms of threat erase the image of Indonesian Muslims as a polite, tolerant and peace-loving nation. Literacy efforts are needed in the use of social media in Indonesian society so that they can become wise social media users in receiving hoax information.

\section{References}

Adiprasetio, et.al. "Hoax, Reproduksi dan Persebaran: Suatu Penelusuran Literatur." Jurnal Pengabdian Kepada Masyarakat 1, no. 4 (2017).

Akhmadi, Agus. "Moderasi Beragama dalam Keragaman Indonesia." Jurnal Diklat Keagamaan 13, no. 2 (2019).

Assegaf, Setiawan, "Evaluasi Pemanfaatan Media Sosial Sebagai Sarana Knowledge Sharing," Jurnal Manajemen Teknologi 16, no. 3 (2017).

Assiddik, Gallant Karunia. "Kajian Identifikasi dan Upaya Penangkalan Pemberitaan Palsu (Hoax) Pada Pembelajaran Bahasa Indonesia," Kongres Bahasa Indonesia 2018. http://repositori.kemdikbud.go.id/.

Fahri, Mohammad dan Zaenuri, Ahmad. "Moderasi Beragama di Indonesia." Jurnal Intizar 25, no. 2 (2019).

\footnotetext{
${ }^{30}$ Reno Fernandes, et.al., "Optimalisasi Institusi Pendidikan Sebagai Upaya Pengendalian Hoax," ABDI: Jurnal Pengabdian dan Pemberdayaan Masyarakat 1, no. 1 (2019): 17.
} 
Vol. 2 No. 1, 2020

Fathurokhmah, Fita, "Menghadapi Krisis Hoax di Media Sosial: Jurnalisme Online dalam Regulasi Media di Indonesia." In Aep Wahyudin dan Manik Sunuantari, Melawan Hoax di Media Sosial dan Media Massa. Yogyakarta: Turstmedia Publishing, 2017.

Gumilar, Gumgum, et.al. "Literasi Media: Cerdas Menggunakan Media Sosial dalam Menaggulangi Berita Palsu (Hoax) oleh Siswa SMA." Jurnal Pengabdian pada Masyarakat 1, no. 1 (2017).

Heriyanto, Gun Gun. "Hoax dan Krisis Nalar Publik: Potret Perang Informasi di Media Sosial." In Aep Wahyudin dan Manik Sunuantari. Melawan Hoax di Media Sosial dan Media Massa. Yogyakarta: Turstmedia Publishing, 2017.

Juditha, Chriatiany, "Interaksi Komunikasi Hoax di Media Sosial Serta Antisipasinya." Jurnal Pekommas 3, no. 2018.

Kaplan, Andreas M., dan Haenlein, Michael. Social Media: Back to the Roots and Back to the Future. Paris: ESCP Europe, 2010.

Users of the World, Unite! The Challenges and Opportunities of Social Media. Indiana: Business Horizon, 2010.

Kottler, Philip, and Keller, Kevin Lane. Handbook of Research of Effective Advertising Strategies in the Social Media Age. Cambridge: IGI Global, 2016.

Majid, Abdul. "Fenomena Penyebaran Hoax dan Literasi Bermedia Sosial Lembaga Mahasiswa Universitas Muslim Indonesia." Jurnal Komodifikasi 8 (2019).

Molina, Maria D., et.al. "'Fake News' is Not Simply False Information: A Concept Explication and Taxonomy of Online Content." In American Behavioral Scientist. California: SAGE Publications, 2019.

Mulawarman dan Nurfitri, Aldila Dyas, "Perilaku Pengguna Media Sosial beserta Implikasinya Ditinjau dari Perspektif Psikologi Sosial Terapan.” Buletin Psikologi 25, no. 1 (2017).

Nurudin, "Media Sosial Baru dan Munculnya Revolusi Proses Komunikasi," Jurnal Komunikator 5 (2010).

Pakpahan, Roida, "Analisis Fenomena Hoax di Berbagai Media Sosial dan Cara Menanggulangi Hoax." Prosiding Konferensi Nasional Ilmu Sosial dan Teknologi (KNiST), 2017.

Rahadi, Dedi Rianto. “Perilaku Pengguna dan Informasi Hoax di Media Sosial.” Jurnal Manajemen dan Kewirausahaan 5, no. 1 (2017).

Sumadi, Eko. "Dakwah dan Media Sosial: Menebar Kebaikan tanpa Diskriminasi." Jurnal AlTabsyir 4, no. 1 (Juni 2016).

Taprial, Varinder, and Kanwar. Priya, Understanding Social Media. London: Ventus Publishing ApS, 2012.

Tim Penyusun Kementerian Agama RI. Moderasi Beragama, Jakarta: Badan Litbang dan Diklat Kemeterian Agama RI, 2019.

Utami, Pratiwi. "Hoax in Modern Politics: The Meaning of Hoax in Indonesian Politics and Democracy.” Jurnal Ilmu Sosial dan Ilmu Politik 22, no. 2 (2018). 